\title{
TRAGEDIA Y DEMOCRACIA GRIEGA: EL IN-FORTUNIO DE LA STÁSIS ${ }^{1}$
}

\author{
Juan Pablo Arancibia Carrizo \\ Universidad de Santiago de Chile \\ Juan.arancibia@usach.cl
}

\begin{abstract}
RESUMEN / ABSTRACT
En la historia de la filosofía, las referencias a la tragedia y los motivos trágicos configuran un ámbito de pensamiento. En la filosofía moderna, tras los estudios de Goethe, Schlegel, Schiller, Hegel, Hölderlin, Schopenhauer o Nietzsche, se instauró una "filosofía trágica" (Rosset 2010), y un "sentido trágico" (De Unamuno 1984; Gentili; Garelli 2015) como principio explicativo de la "trágica experiencia política moderna" (Williams 2014; Eagleton 2011). Inscrito en el registro de una filosofía de "lo trágico", el presente texto propone un estudio genealógico de la relación entre tragedia y democracia griega, mediante el examen de la categoría de stásis.
\end{abstract}

Palabras ClaVE: tragedia, democracia, stásis, krátos, dêmos, pólemos.

\section{TRAGEDY AND GREEK DEMOCRACY: MIS-FORTUNE OF THE "STASIS"}

In the history of philosophy, references to tragedy and tragic motives constitute a field of thought. In modern philosophy, after the studies of Goethe, Schlegel, Schiller, Hegel, Hölderlin, Schopenhauer or Nietzsche, a "tragic philosophy" (Rosset 2010) and a "tragic sense" (De Unamuno 1984; Gentili; Garelli 2015) were established as an explanatory principle of the "tragic modern political experience" (Williams 2014; Eagleton 2011). In the register of a philosophy of "the tragic", the present text proposes a genealogical study of the relationship between tragedy and Greek democracy, through the examination of the category of "stasis".

Keywords: Tragedy, Democracy, Stasis, Krátos, Dêmos, Pólemos.

\section{Introducción}

$\overline{R A}$ La relación entre lo trágico y lo político se ha tornado un tópico relevante en el pensamiento contemporáneo, y no ha cesado de reaparecer en diversas lecturas filosóficas. Se postula que la dimensión trágica contiene y activa la materia prima de la política: el conflicto (Rinesi 2011); que la tragedia es la escena de apertura histórica,

1 El presente artículo constituye un avance parcial de investigación del Proyecto Fondecyt de Iniciación 2019-2022, N¹1190173, "Estudio de la categoría de stásis en la Tragedia y Democracia griega. Hacia una genealogía trágico-política de la democracia". 
portadora del carácter esencial de la experiencia política moderna (Grüner 2007); y que el devenir de la política contemporánea, reconoce en "lo trágico" su clave explicativa fundamental (Critchley 2014).

Tonalidad familiar se reconoce en trabajos de George Simmel (1998), Max Scheler (1996), Karl Jaspers (1960), Jacques Lacan (1986), Gilles Deleuze (1998), Judith Butler (2001), Terry Eagleton (2011), George Steiner (2011), Raymond Williams (2014), hasta en investigaciones más recientes como las de Rebok (2012), Gentili \& Garelli (2015), Andrade (2003), Scodel (2014), Boccon (2008) o Gallego (2003-2018). Se constata allí la coimplicancia genealógica de tres procesos históricos: la emergencia de la tragedia (Lesky 2009, p. 397), la configuración racional de la comunidad política (Vernant 2004: 133) y la constitución de la democracia (Forrest 1966, p. 16).

El nacimiento de la tragedia comporta una irrupción estético-literaria que transforma el régimen poético (Cataudella 1967, pp. 58-64), modifica la escenificación del teatro, los ritos y fiestas públicas (Adrados 1972, pp. 21-57), pero muy especialmente, afecta al ordenamiento político, la concepción de la ley, y la práctica público-política (Vernant;Vidal-Naquet 2002, pp. 17-21). La tragedia surge y se desarrolla en un periodo histórico de profundas transformaciones que cruzan la época de decadencia de las monarquías micénicas, la supremacía de las tiranías, hasta la conformación misma de la democracia (Cohen 1961, pp. 113-124; Wilcken 1959, pp. 258-263). Entonces, el periodo de emergencia, esplendor y decadencia de la democracia es acompañado casi exactamente con el nacimiento y declinación de la tragedia. Al igual que los orígenes de la democracia, que enraízan en las reformas de Solón, las primeras tragedias se estrenaron en el belicoso siglo VI a. C. bajo las iniciales representaciones de Tespis en 534 a. C. (Iriarte 1996, pp. 5-16).

Esta correspondencia histórica entre tragedia y democracia se constata en el proceso de configuración de un pre-derecho griego en torno a los problemas de la justicia (dike) que se debaten en la ciudad democrática, y que serán representados como motivos propiamente trágicos (Gernet 1982, p. 98). Así, los grandes autores trágicos -Esquilo, Sófocles y Eurípides- vinculan sus obras directa o tangencialmente a los contextos de discusión política y los conflictos de la emergente democracia (Murray 1947, pp. 252-305).

Significativo es que Esquilo haya participado en las Guerras Médicas, en el triunfo de Maratón 490 a. C., en las batallas de Salamina 480 a. C. y en la victoria de Platea 479 a. C., hecho que quedará registrado en su obra "Los Persas" (Cataudella 1967, p. 106). El propio Esquilo - que conoció y vivió bajo las reformas democráticas de Clístenes-, hace temprana referencia a la idea de democracia en la declamación del rey Pelasgo en "Las Suplicantes" (Esquilo 2012, pp. 365-400). Será precisamente en esta tragedia que, por primera vez en la literatura griega, se ocupa la articulación entre la expresión "dêmos" y "krateín” (Vidal-Naquet 2004, p. 46).

Esquilo escribe la Orestíada en la primavera de 458 a. C., tras la reforma del Areópago impulsada por Efíaltes. Será en la última pieza de esta trilogía, "Las Euménides", que se expresará nítidamente la instauración de la emergente racionalidad e institucionalidad democrática destinada precisamente a superar la amenaza de la 
guerra civil (Mas 2003, pp. 89-99). Así, “Las Euménides”, consagra el triunfo de la pólis democrática sobre la violencia (Rocco 1996, p. 182).

Significativo también resulta que Sófocles haya vivido bajo las reformas democráticas de Pericles, y tras vencer en las fiestas Dionisias con la representación de "Antígona" (442 a. C.,), fuera escogido como estratega y uno de los diez generales -junto a Pericles y a Tucídides- enviados a reprimir la rebelión de Samos (Cataudella 1967, pp. 138-139). Asimismo, sensible resulta el hecho de que en las Dionisias del 415 a. C., en el decimoséptimo año de la guerra del Peloponeso, tras la invasión y destrucción con que la democracia de Atenas devastara la isla de Melos, y tras la invasión y anexión de Sicilia, Eurípides haya escrito su más cruenta tragedia, "Las Troyanas". Obra que fue entendida como crítica a la política imperial de Atenas, pues exhibía la

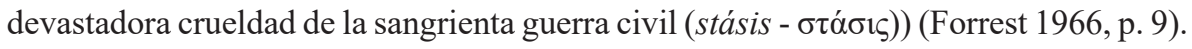

Así, la tragedia nace, convive y acompaña todo el proceso de emergencia, esplendor y decadencia de la democracia ateniense. El propio Eurípides lo expresa en "Orestes" (408 a. C.), aludiendo a la aguda conflictividad atravesada por Atenas tras el golpe de los Cuatrocientos, la restauración democrática y el castigo de los oligarcas. Como explica Gallego, en el retorno al mito abordado por Esquilo en la "Orestíada" para pensar el nacimiento de la democracia, exactamente medio siglo después, Eurípides presenta una mirada diferente en torno a su crisis y oclusión (Gallego 2014, p. 7).

Es en ese marco histórico de la Grecia Clásica que, tras complejas y cruentas mutaciones, se produce el encuentro entre tragedia y democracia; encuentro del teatro y la pólis, como escenario del discurso público-político (Canfora 2014, pp. 138-158). Allí, paulatinamente, se irán asentando los principios de libertad, igualdad, pluralidad, derecho y justicia, que posteriormente cristalizan el concepto mismo de democracia (Vernant 2004, pp. 133-142). De modo que tragedia y democracia se van trenzando desde su inicio, como el espacio agónico donde discursivamente los hombres se confrontan en fuerza, lenguaje y razón, para afirmar su derecho, justicia y gobierno (Lesky 2001, pp. 254-259). Es así "como los ideales de justicia, libertad, derecho o democracia, todos los tópicos de la vida social griega, se encuentran presentes en el corazón mismo de todas las tragedias..." (García 2006, p. 68). Evidentemente, la producción teatral forma parte de las configuraciones políticas de la democracia radical ateniense, tanto en el momento de la instauración como en el de la extenuación de sus prácticas y sus formas de pensamiento (Gallego 2011, p. 159).

Los orígenes de la tragedia señalan con inmediatez su intrincado y complejo carácter político y su implicación en los cambios democráticos (Vernant; Vidal-Naquet 2008), donde la tragedia poseía rango de culto de gran solemnidad para la vida de la pólis (Burckhardt 1965, pp. 273-281), pues, asistir a la tragedia constituía un acto patriótico, ciudadano, moral y religioso (Vidal 2007, p. 12). De este modo, la tragedia anuncia la configuración de una nueva judicatura política de la ciudad, es "la expresión del triunfo de los valores colectivos impuestos por la nueva ciudad democrática" (Vernant; Vidal-Naquet 2008, p. 12).

Esta inmediata y evidente conexión histórica, tangencia una segunda imbricación de naturaleza estrictamente analítica que define una ligazón interna, propiamente 
filosófica, entre tragedia y democracia. Esta relación está articulada por la categoría clásica griega de stásis, entendida como aquella guerra civil que libra la comunidad contra sí misma, lo que configura y desata el carácter trágico de la democracia (Loraux 2005, pp. 51-81). La tragedia desata la guerra y contrariedad en la familia, en lo más íntimo y seguro: ahí donde creíamos habitaba el amor y la confianza, se desencadena "la suspicacia, el asco, y el deseo mortal de herir al otro, alli donde es más profundo el dolor" (Schadewaldt 1981, p. 47).

\section{Tragedia y Democracia: una axiomática agonística}

Luc Ferry sostiene que la tragedia griega es la negación de la democracia, en cuanto ésta desata el conflicto cruento sobre la comunidad que se debate entre un destino fatal y la libertad. La democracia sería la afirmación de la autonomía y la libertad, sería una "revuelta" contra la tragedia, pues instaura la lógica de legalización de las condiciones de la libertad ${ }^{2}$. Nuestra lectura postula que la tragedia no solo sería el reverso que tensiona la democracia, sino que es, al mismo tiempo, su condición de posibilidad, en cuanto la tragedia comporta condiciones discursivas y subjetivas preliminares para la emergencia de la democracia. La democracia se constituye en relación y con ocasión de la "tragedia".

La democracia, como la tragedia, está constituida a partir del mismo riesgoso

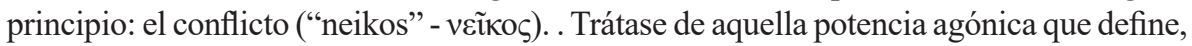
divide y reúne a la comunidad política. De allí que la tragedia, como la democracia, consista en la indefectible pulsión de morar y lidiar con el conflicto, intentando perdurar sin sucumbir ante aquella energía de contradicción y antagonismo que presentan, en toda época, las vidas y relaciones entre los hombres. Como afirma Festugière, la tragedia de Esquilo, Sófocles y Eurípides enseña precisamente el sentido trágico de la vida, como el advenimiento irreductible donde las catástrofes humanas son constantes en todo tiempo y nación (1986, p. 15). Por ello, la tragedia y la democracia poseen la capacidad de vivenciar y concebir el conflicto como su principio constitutivo (Rinesi 2011, p. 11).

Históricamente, constatamos que la democracia nace entreguerras: las Guerras Médicas desatadas en 499 a. C. a partir de la rebelión jonia contra la invasión persa, hasta el 479 a. C. con la victoria en Platea bajo la dirección de Pausanias (Heródoto 2000, V, 28, 126). Más tarde se suscita la intestina guerra del Peloponeso entre 431 y 404 a. C., desatada por el imperio de la democracia ateniense (Tucídides 2000, I, 23, 45). Sea, cercada históricamente por la guerra contra un enemigo externo (pólemos); sea, apremiada por la guerra civil interna (stásis), lo cierto es que la democracia griega nace contorneada por la experiencia trágica de la guerra (Cohen 1961, pp. 47. 52).

2 "Le tragique Grec, une catégorie de la pensée plus actuelle que jamais". Conferencia pública dictada en París, en 14 de enero de 2016. 
De allí que nuestra hipótesis de lectura consiste en comprender a la democracia como un dispositivo de guerra, en cuanto ella nace de la experiencia de la guerra y se constituye históricamente como una tecnología política destinada a convivir y a desplegarse en los contornos internos y externos de la guerra ${ }^{3}$. Así, la democracia nace y se comporta históricamente -desde su inicio hasta nuestros días-, como el borde crítico e inestable, como límite interior y exterior de la guerra; como tecnología política de prevención y de ejecución de la guerra.

Ceñida y asediada por una conflictividad histórica que la apremia, la democracia sucumbe, en ocasiones, ante la violencia de un enemigo externo pólemos; y en otras, ante el enfrentamiento interno que desata su ruptura institucional: stásis (Canfora 2014, pp. 158-162). Si bien será preciso posteriormente elucidar la distinción y la relación entre stásis y pólemos, podemos preliminarmente sostener que el carácter agónico será un principio constitutivo de la democracia (Gallego 2003, p. 189) y este principio será un signo unificador entre tragedia y democracia.

Esta condición bélica de la democracia se notifica en su propia etimología. El

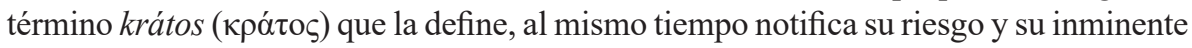
posibilidad. Ese krátos, es entendido como un poder cruento, aplastante y desmedido tras la victoria (Loraux 2005, pp. 212-214). En su desborde "stásico", el krátos deviene "trágos", "tragodói”, hédor y sacrificio del hombre ante la muerte (Burkert 2011, pp. 45-73). El término griego krátos remite a una supremacía en el enfrentamiento o

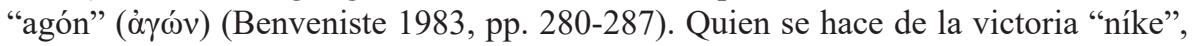
ejerce un dominio:

Dentro de la ciudad, krátos, es una palabra desprestigiada. De ahí que ya en el siglo V los demócratas eviten insistentemente el término "demokratía". Pero al evitar pronunciar un nombre que quizá ha sido impuesto al régimen por sus adversarios como el más despectivo de los apodos, toman a su cargo la representación oligárquica del régimen y admiten implícitamente que "demokratía" significa que la ciudad sufrió una división (Loraux 2008, pp. 67-68).

El sufijo krátos remite a la fuerza, a la imposición violenta (" $\beta i \alpha-\beta i \alpha ́ \zeta \omega ”)$, haciendo

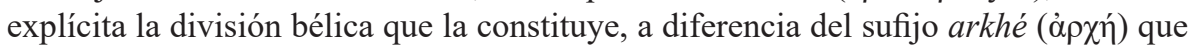
remite a un poder legítimo y fundado en un principio (Cassin 2010, pp. 1022-1029). Entonces, significativo es que en la Grecia Clásica no se constate ni se refiera a la existencia de una demarquía (Nancy 2010, pp. 72-73). La democracia, incluso en el "siglo de oro" de Pericles, estuvo marcada por la conflictividad interna, la violencia y la crueldad (Canfora 2014, pp. 13-24). La política griega exaltaba el conflicto y el desacuerdo, la indefinición de los poderes democráticos era fuente de luchas que excedían la capacidad estatal de representación de esos conflictos. "La democracia

Trátase de un dispositivo en cuanto concierne a condiciones específicas de enunciabilidad, visibilidad, audibilidad y líneas de fuerza (Deleuze 1987:75-88; Deleuze 1999: 155; Agamben 2014: 7-26). 
como soberanía del pueblo queda representada, en cuanto a su principio activo, por el término krátos, que nos señala la presencia de una fuerza más que de un gobierno" (Gallego 2003, p. 189). Esto se encontraría evidenciado en el propio discurso del Pericles tucidideo, al exaltar "la violencia imperial de Atenas por sobre toda la superficie de la tierra". Allí, las palabras griegas precisas que Tucídides pone en boca de Pericles son: "las voluptuosidades del triunfo y de la crueldad" (Tucídides 2000, II, 41, 4).

Esta condición agónica -"polémica" y "stásica"- de la democracia ateniense suspende o tensiona aquella delimitación entre lo interior y lo exterior, sugiriendo más bien un riesgoso carácter de indeterminación de la propia fuente de la que emana su poder y su conflicto. "Edipo en Colono" de Sófocles, por ejemplo, no remite a una guerra real entre dos ciudades, sino que pone de relieve la división inherente a la stásis ateniense. Precisamente esta tragedia de-situando el interior-exterior, mediante el oxímoron de xenostasis hace comparecer a la propia democracia ateniense como la portadora y promotora de su propio conflicto y división (Gallego 2016, pp. 160-172).

Esa división deviene en la devastación y catástrofe sobre la ciudad. Así, la stásis de la demokratía deviene en demo-tragoidía. Una temprana noticia de aquélla la encontramos en los cruentos acontecimientos de Corcira, al inicio de la Guerra del Peloponeso (Tucídides 2000, III, 69-84,3). Bowra sostiene que será precisamente ese contexto de la barbarie de la guerra -interna y externa-, la que enseña a Sófocles el afán de venganza y la dureza de corazón que nace entre los hombres por los agravios e injusticias sufridos. En toda la extensión de la tragedia, sea en Electra, en Agamenón, en Coéforas, en Medea, en Orestes o en Las Bacantes, se constatan las oscuras pasiones que desata la venganza (Bowra 1948, p. 81). Así nos lo narra Tucídides:

...hombres que no actuaban por codicia, sino que se movían contra sus adversarios desde posiciones de igualdad, podían llegar a perpetrar, cruel e inexorablemente, al ser arrastrados por el desenfreno de su cólera a los excesos más graves. La vida de la ciudad se vio trastornada en el curso de esta crisis, y la naturaleza humana, habituada ya a cometer injusticias a despecho de la legalidad, se impuso entonces sobre las leyes y encontró placer en demostrar que no era señora de su propia cólera... (Tucídides 2000, III, 84,1-2).

Advertido de esta desmesura de la stásis, Aristóteles explica la tragedia por la kátharsis, como aquella descarga y purgación de las acciones que habrían violentado un orden (Aristóteles 1999a, 1455b, 14-30), y como purificación de ciertos males que aquejan y se apoderan de los hombres (Aristóteles 1999b, VIII, 1341a, 20). En razón de aquello, Rodríguez Adrados sostiene como hipótesis que será la tragedia de la guerra lo que precipita el desenlace calamitoso de la democracia, pues los afanes bélicos por una guerra exterior desembocan en la guerra civil interior y consecuente ruina de la democracia (Rodríguez Adrados 2011, pp. 165-182). Sin embargo, la guerra desatada en la crisis de la democracia, debido a los errores o las irresponsabilidades del dêmos en la construcción histórica de la democracia radical, lejos está de ser el correlato de una tiranía (Gil 2009, pp. 57-61). 
Compleja e intrincada se torna la nervadura que trama la tragedia con la democracia, ambas cruzadas y hermanadas por la stásis, al rango que, podríamos decir, la stásis comporta la tragedia de la democracia, al tiempo que la democracia pulsa por impedir la tragedia de la stásis que la acosa. La stásis asedia la ciudad pero -como señala Nicole Loraux (2008)-, se la oblitera haciéndola aparecer como guerra externa, generalmente tebana, para que Atenas siga siendo la referencia política de la ciudad única y sin conflicto. Por ejemplo, en "Edipo en Colono", donde la ciudad de Colono es propuesta como símbolo de la pretendida unidad de Atenas, capaz de unificar a la élite y el pueblo llano, enfrentados en la stásis extrema que atraviesa a la sociedad ateniense (Gallego 2014, pp. 2-7).

Así, la transitividad de la democracia a la tragedia se suscita mediante la stásis. Cuando el krátos de la democracia desencadena la tragedia de la stásis, de la política democrática, sucumbimos a la política "demotrágica": "Así, la guerra civil se va adueñando de las ciudades" (Tucídides 2000, III, 82, 3). En ella, la tragedia trenza dos poderosas fuerzas, la virtud heroica con la crueldad y el desenfreno de la hybris (v̈ßpı)). Las entrelaza en una unión indiscernible en la propia figura del héroe: grandeza de corazón y locura noble; fuerza incontenible y bravura de espíritu. Yace ahí un agente cuya potencia y poderío gestan una afirmación que le conduce a su propia destrucción: "una grandeza y un peligro todo interior" (Schadewaldt 1981, p. 50).

De allí que la figura del héroe cruce toda una mitología trágica y política de la democracia, pues desde las Guerras Médicas hasta la Guerra del Peloponeso se cuentan innumerables historias de héroes y dioses que en las batallas luchaban con desenfreno para proteger la ciudad (Persson 1956, p. 289). En coherencia con ello, Schadewaldt sugiere que este carácter trágico del héroe de la democracia se aprecia en Sófocles, cuando éste describe el arrebatador impulso de avance del hombre democrático en la era de Pericles, quien "unas veces resbala hacia el mal, otras hacia el bien. Honra la ley y el derecho, pues es preeminente en la ciudad. Y sin paz se lanza y arroja cuando a lo innoble se une en osadía" (Sófocles 2000, pp. 365-375).

Paradójicamente, aquel desenfreno de la democracia, aquello que la destruye e interrumpe, su peligro mayor, proviene de su propia inmanencia. Es la propia conflictividad democrática que la define y constituye, lo que la amenaza con su colapso (Todorov 2017: 185-189). En su desborde, la stásis desencadena la hybris democrática que se cierne devastadora sobre y contra la propia democracia (Vernant 2007, pp. 51-88). En ese sentido, la política trágica aparece como una "antipolítica", toda vez que, "antipolíticas" serán todas las actitudes y acciones que exceden el orden cívico (Gallego 2003, p. 416).

\section{Stásis, Tragedia y Democracia}

En el año 594 a. C., tras ser electo para el arcontado, Solón emprende una reforma de la Constitución y las leyes atenienses postulando el principio de "eunomía" (García Gual 2018, pp. 77-88). Si bien Solón no sería propiamente un "demócrata”, sino más bien un "constitucionalista", las reformas que promulga, sientan bases sólidas para que 
germine paulatinamente en el dêmos un ethos democrático (Forrest 1966, p. 175). Estas transformaciones cobran un acentuado carácter político de mitigación de la opresión social de ese entonces, reduciendo los privilegios de la aristocracia y mejorando la vida del dêmos y los campesinos (Wilcken 1959, p. 150).

Solón, consciente del riesgo que representaba una rebelión campesina aliada a una tiranía, proclama la supresión de los impuestos, condona las deudas y suprime la esclavitud por deudas (Aristóteles 2016, 5.1-12.5). Promulga un conjunto de leyes públicas y crea un Consejo de cuatrocientos miembros, paralelo al Areópago, que anticipa la futura "Bulé” de Clístenes (Mossé 2016, pp. 16-18).

Estas reformas se encaminan hacia la futura democracia y se emprenden bajo un contexto de agudos conflictos que Solón intentaba apaciguar. Empero, sus esfuerzos como mediador y sus concesiones a uno y otro bando para poner fin a las luchas internas resultaron inútiles, pues al terminar su mandato, se encendieron nuevas guerras civiles de tal violencia que las elecciones para el arcontado estuvieron suspendidas durante años (Wilcken 1959, p. 154). Tras las disputas internas de tres partidos -los grandes propietarios pediakoí, la población industrial y mercantil parálioi, y el pueblo miserable de las montañas diákoi- en 561 a. C. consigue imponerse el aristócrata Pisístrato, jefe del partido campesino, simulando un intento de asesinato en su contra: "El pueblo de Atenas, engañado, le permitió escoger entre sus ciudadanos a trescientos hombres armados con mazas de madera que lo escoltaron. Esos hombres se sublevaron con Pisístrato y ocuparon la acrópolis" (Heródoto 2000, I, 59).

Más tarde Pisístrato fue derrocado provisionalmente, y años después retoma el poder, tras organizar un ejército de mercenarios apoyado por fuerzas extranjeras, restableciendo su tiranía hasta su muerte en 528 a. C. Herederos del tirano, Hipías e Hiparco gobiernan hasta el tiranicidio de Hiparco cometido por Harmodio y Aristogitón, hecho que desencadena el recrudecimiento de las hostilidades, hasta la intervención del rey de Esparta, Cleómenes, en 510 a. C. poniendo fin a la tiranía pisístrata (Mossé 2016, pp. 18-25).

Aquellos acontecimientos suscitan la gran revolución de Clístenes, tras la disputa con otras facciones aristocráticas lideradas por Iságoras, que bajo la presión militar del ejército espartano fue electo para el arcontado en 508 a. C. Clístenes emprende un proceso de profundas reformas que darán nacimiento a la democracia. Conserva las cuatro phyles religiosas y aristocráticas, pero crea diez nuevas phyles territoriales, donde el parentesco sanguíneo era ficticio; suprime los rangos de privilegio de la ciudad, divide el Ática en tres regiones, logrando un equilibrio de las fuerzas, se declara la igualdad entre los ciudadanos ("isegoría" e "isonomía"); se reorganiza el Consejo de los Quinientos, que reposa bajo el mando equilibrado del dêmos de cada phyle; instituye el ostracismo como medio de salvaguarda de la naciente democracia. Así, Clístenes figura como temprano fundador de la democracia ateniense, donde

el soberano responsable del Estado era el pueblo que, a través de su órgano representativo, la Asamblea, decidía en los asuntos exteriores sobre la guerra, la paz y las alianzas, ejercía en el interior las tareas legislativas y de control de los 
funcionarios, otorgaba la ciudadanía y en los tribunales jurados dictaba en última instancia sus sentencias inapelables (Wilcken 1959, p. 158).

Antes de culminar el siglo VI, en 506 a. C., el nuevo orden democrático se vio amenazado por una peligrosa ofensiva exterior, atacado al mismo tiempo por lacedemonios, beocios y calcidios. Los atenienses derrotaron a sus enemigos y tras su victoria ampliaron sus terrenos en las llanuras de Calcídica. Pues, salvo breves pasajes de paz persa-helénica, la democracia de Atenas estuvo amenazada por fuerzas bélicas constantemente (Wilcken 1959: 159). Asimismo, al crear las nuevas tribus, Clístenes integró más estrechamente a las diferentes partes del Ática y creó la "ciudad-nación” que, unida, podía enfrentar el peligro de la guerra con los medos (Mossé 2016, p. 27).

Esquilo atiende precisamente al contexto de esta cruenta guerra, enseñando la desolación y humillación con que la fuerza reduce a los hombres, un instante creídos invencibles, y un instante más tarde postrados ante la devastadora derrota: "Han muerto, sí, los jefes del ejército. ¡Ay! ¡Ay! ¡Que dolor! ¡Qué pena! ¡Deidades causaron un inesperado desastre! ¡Inunda tus ojos de lágrimas! Entre lamentos marcha a tu casa... ¡Ay, pena y dolor de los que murieron!” (Esquilo 2000, pp. 1005,1075).

Si en "Los Persas" se contempla una Atenas victoriosa ante Persia, más tarde la propia Atenas sucumbirá estrepitosamente ante Esparta en la stásis de la liga del Peloponeso. Entonces, de qué trata la tragedia sino de la cuestión del enemigo, especialmente el modo en que el otro se convierte en enemigo. Por ello Esquilo representa al enemigo derrotado no con aire triunfalista, sino con compasión, casi anticipando la humillación que traería sobre Atenas la desmesura de la hybris en la guerra del Peloponeso (Critchley 2014, p. 31).

El motivo trágico del asesinato entre parientes, que viene a simbolizar en la tragedia la pesadilla griega de la guerra civil -ese enfrentamiento sanguinario entre los ciudadanos concebido como el peor de los males cívicos- es la imagen con que los trágicos reproducen una ciudad escindida y enfrentada contra sí misma (Iriarte 1996, p. 35).

En una sensibilidad semejante existen diversas lecturas que disienten del mito pacificador de la democracia como superación del conflicto. Froma Zeitlin, por ejemplo, sostiene que en "Las Euménides" -obra tenida por símbolo de la reconciliación- lejos de ser la escena donde fuerzas opuestas alcanzan un estado de armonía y justicia, más bien, se impone un orden de jerarquización de valores: la subordinación de las Erinias a los olímpicos, lo bárbaro a lo griego, lo femenino a lo masculino, etc. Zeitlin sostiene que la democracia nunca extingue el conflicto, sino que mediante la retórica democrática de la igualdad, la razón y el consenso, se legitima la institucionalización de polaridades excluyentes, en vez de crear un orden auténticamente democrático. Así, la "Orestíada" puede ser entendida como un documento fundacional de la civilización occidental, pero lo que funda es una tradición de "exclusión y misoginia" (Zeitlin 1978, p. 149).

El año 462 a. C. los demócratas radicales bajo la dirección de Efialtes -líder del partido de la democracia radical-, dan un golpe de Estado a Cimón, emprendiendo un 
conjunto de reformas profundas, como despojar al Areópago de sus derechos políticos y preservarle solo la jurisdicción criminal, sus facultades fueron transferidas al Consejo de los Quinientos, a la Asamblea popular y a los Tribunales Jurados. Este escenario desencadena las hostilidades y Efialtes resulta asesinado por los aristócratas. Tras la muerte de Efialtes asume Pericles en 461 a. C. profundizando y consolidando el imperio democrático de Atenas (Wilcken 1959, pp. 203-205).

La expansión imperial de la democracia ateniense, para preservar su dominio, no podía sino considerar el ejercicio de la guerra como condición de su poderío. Entonces la responsabilidad de Pericles en la Guerra del Peloponeso es consustancial al comando que ejercía la democracia (Plutarco 2000, XXIV-XXXVII), "puesto que es obvio que la guerra entraba en la lógica de su política. La democracia ateniense estaba condicionada al mantenimiento del Imperio. Cualquier amenaza que pesara sobre el Imperio era una amenaza directa contra su régimen" (Mossé 2016, p. 51).

Aristóteles también identifica esta riesgosa nervadura y contigüidad entre democracia y stásis, (1999b, IV, 1291b, 22-1292a, 29), y al clasificar las distintas democracias, advierte de aquéllas que devienen violento "caudillaje de muchos", pues azotan y arruinan la ciudad (Aristóteles 1999b, V, 1309b, 9-1310a, 16), al tiempo que previene de los diversos tipos de sublevaciones, guerras y crisis políticas, bajo la expresión de "enfermedades políticas" que amenazan a la ciudad (Aristóteles 1999b, V, 1301a, 8-1305b). Aristóteles ha tenido presente el relato de Tucídides, quien describe la inclemencia desatada de la stásis en los episodios de Corcira:

los corcireos asesinaron a aquellos de sus conciudadanos a los que consideraban enemigos; el cargo que les imputaban era de querer derrocar a la democracia, pero también hubo quienes murieron víctimas de enemistades particulares, y otros, a causa del dinero que se les debía, perecieron a manos de sus deudores. La muerte se presentó en todas sus formas y como suele ocurrir en tales circunstancias, no hubo exceso que no se cometiera (...) A tales extremos de crueldad llegó la guerra civil, y pareció más cruel todavía porque fue una de las primeras; pues más tarde todo el mundo griego fue presa de la agitación (...) Muchas calamidades se abatieron sobre las ciudades con motivo de las luchas civiles, calamidades que ocurren y que siempre ocurrirán mientras la naturaleza humana sea la misma. (Tucídides 2000, III, 81, 2-82, 3).

Se pone en evidencia así la relación entre tragedia y democracia griega a partir del acontecimiento de la stásis. No resulta casual que una de las investigadoras contemporáneas más relevantes en el estudio de la stásis titule uno de sus trabajos consagrados al tema como: "La Tragédie d'Athènes" (Loraux 2005). Allí, la stásis es concebida como una tragedia, y muy particularmente como la tragedia de la democracia ateniense. En este estudio, Nicole Loraux pretende complejizar el concepto de stásis, en el entendido de que ya no se puede reducir ésta a un accidente o incidente de la pólis griega, a la que suele representársela normalmente en paz, solo momentáneamente quebrantada por un estadio transitivo y circunstancial de guerra. Loraux se opone a esa representación, precisamente sosteniendo que aquella manera de conceptualizar la stásis estaría 
invalidada por la incapacidad esencial de tratar el conflicto interior como constitutivo de la definición griega de lo político (Loraux 2008, p. 52).

Loraux parece comprender a la stásis como un principio constitutivo de lo político, resistiéndose a un estatuto conceptual meramente episódico y accidental. La esencia misma de la stásis, afirma, consiste en ser la generalidad misma del conflicto en la ciudad. Por ello Tucídides se refiere a la guerra del Peloponeso como: la ciudad está "tomada por la guerra civil", stásis (stasiásasa), o que "los ciudadanos están enfrentados" (stasiasánton). En virtud de esta lógica, afirma Loraux, el verbo stasiázo ( $\sigma \tau \alpha \sigma i \alpha ́ \zeta \omega)$ no debería tener más sujeto que la colectividad indivisa de los ciudadanos, como si este enfrentamiento afectara a la totalidad de la ciudad (Loraux 2008, p. 64).

Giorgio Agamben precisa a Loraux que, más que resaltar el nexo entre stásis y familia, entre stásis y oikos -entendida como el conflicto familiar posándose sobre la pólis - en cuanto la guerra civil asimila y torna indistinguibles al hermano y al enemigo, más bien, la stásis constituye ante todo un umbral de indiferencia entre "oikos" y pólis, entre parentesco de sangre y ciudadanía. La hipótesis de Agamben es que la stásis no tiene lugar, ni en el "oikos" ni en la pólis, sino que la stásis constituye un umbral de indiferencia entre el espacio impolítico de la familia y el político de la ciudad (Agamben 2015, p. 23).

Esta misma precisión nos resulta histórica y analíticamente relevante, pues contribuye a complejizar la distinción entre pólemos y stásis. Si bien el pólemos designa a la guerra contra un enemigo externo, es necesario precisar que bajo el marco de la guerra externa, en la ciudad se produce un conjunto de sediciones, facciones y defecciones internas, que desatan acciones cruentas, semejantes a la stásis. El año 479 a. C., por ejemplo, tras el triunfo en Platea, los aliados griegos se dirigieron hacia Tebas dispuestos a imponer su castigo a la ciudad por su defección y complicidad con los persas. A consecuencia, Tebas capituló y perdió su hegemonía en la confederación beocia (Wilcken 1959, p. 195).

Insistiendo en nuestra hipótesis, señalamos que la demokratía emerge y se configura en este campo de hostilidades y amenazas que la fuerzan, en su propia configuración, a definir(se) (como) una política del conflicto. Dicho de otro modo, la guerra externa no solo opera como el decorado contextual que delimita el nacimiento de la democracia, sino que es una condición posibilitante para su gestación, pues solo en posición victoriosa y hegemónica tras las guerras médicas, Atenas genera y despliega condiciones políticas, jurídicas, económicas, logísticas y militares para la consolidación del ideario e institucionalidad democrática, su expansión y hegemonía. Asimismo, serán esas mismas condiciones las que van precipitando y acrecentando condiciones para desencadenar la guerra civil interna y posterior decadencia democrática (Mas 2003, pp. 89-100).

La relación de fuerzas en liza sería una condición de posibilidad y una condición histórica de emergencia de la democracia. Canfora nos remite al juramento de los oligarcas que declaraba: "yo seré enemigo constante del demo; le haré todo el mal 
que pueda"4 (Canfora 2014, p. 65). Asimismo, a la inversa, después del breve triunfo oligárquico en Atenas el 411, recuperada la democracia se obliga a todos los ciudadanos a un juramento pronunciado en las grandes Dionisas de 409:

Mataré con la palabra, con la acción, con el voto y por mi propia mano, si me fuera posible, a quien derroque la democracia en Atenas, a quien detente un cargo tras el derrocamiento de la democracia y a quien trate de convertirse en tirano o a quien colabore con la tiranía. A quien matare a éstos, yo los consideraré puro ante los dioses ${ }^{5}$ (Canfora 2014, p. 66).

Esta inquietante relación entre stásis y democracia conduce a Loraux a la pregunta: “ ¿qué comprendemos de la stásis? Yo respondería que, al constatar que el verbo stasiázo tiene como sujeto la colectividad de ciudadanos, nos contentamos quizá con verificar el carácter político del proceso" (Loraux 2008, p. 65). Para Loraux, el pasaje de valentía tucididea sobre la stásis, se vincula con la Antígona de Sófocles, en cuanto lleva al exceso las dos partes en conflicto y equilibrio. Sin duda, afirma, Tucídides ha tenido sus razones de peso para proceder a descifrar la stásis bajo una simetría semejante. "Esta razón se llama poder (arkhé) o, más bien, deseo de poder, designado como pleonexía o philotimía, según sea, al pensarse en relación con la posesión o con los honores, avidez o ambición" (Loraux 2008, p. 66).

De allí que, constitutivamente, la democracia esté expuesta, pero al mismo tiempo, conteniendo y comportando el riesgo del conflicto que la constituye: el juego y la disputa por el poder. Allí la stásis no es otra cosa que el desenlace y el despliegue de las apetencias "desmedidas" de las facciones que disputan el poder. Pero, lo "desmedido" de esas apetencias se explica y sostiene precisamente por su estado de posibilidad, es decir, la pleonexía como el movimiento afirmativo del acrecentamiento de poder. De modo que, la simetría de la stásis no ha de consistir en la igualdad de las fuerzas o de las armas -Antígona v/s Creonte-, sino en la igualdad del deseo y la voluntad en liza.

La causa de todos estos males era el deseo de poder inspirado por la codicia y la ambición; y de estas dos pasiones, cuando estallaban las rivalidades de partido, surgía el fanatismo (...) Así fue como la perversidad en todas sus formas se instaló en el mundo griego a raíz de las luchas civiles (Tucídides 2000, III, 82, 3-83).

Sin embargo, afirma Castoriadis, la democracia fracasa precisamente por el impulso democrático de la hybris, porque justamente lo que se había superado como condición para su advenimiento, ahora la recaída en la misma, es signo de su propia degradación (Herreras 2010, p. 114). Quizá este problema haya sido anticipado por el propio Platón, quien en el libro V de la República, en el diálogo sostenido entre Sócrates y Glaucón, establece la distinción entre guerra externa pólemos y guerra civil stásis: “Creo que a

$4 \quad$ El texto referencia a "Sobre el sistema político ateniense". Pseudo Jenofonte. Asimismo a Aristóteles: Política V, 1310a9.

5 El texto referencia a Andócides: "Sobre los misterios", pp. 96-98. 
los dos nombres de guerra y sedición corresponden dos realidades en las discordias que se dan en dos terrenos distintos: lo uno se da en lo doméstico y allegado; lo otro, en lo ajeno y extraño. La enemistad en lo doméstico es llamada sedición (stásis); y en lo ajeno, guerra (pólemos) (Platón 1997b, V, 470a-470b).

A partir de esta distinción, Sócrates afirma que los griegos no harán esclavos a otros griegos, sino solo a los bárbaros. Los griegos entre los griegos no despojarán los cadáveres, no depredarán los campos ni incendiarán las casas de los vencidos. Ante esta prescripción de Sócrates, Glaucón pregunta: “ ¿y es posible que tal organización política exista?" (Platón 1997b, V, 470a-473a). A esta pregunta responde Castoriadis, evidenciando el carácter trágico de la stásis, como la hybris democrática, ahora devenida "demotrágica":

¿Cuál es la condición de la hybris? Que ninguna norma plena de sentido se imponga, que ningún límite externo, fuera de la catástrofe, venga por sí mismo, "naturalmente", a restringir las empresas, las miras, las actividades de los humanos. De manera que la hybris no puede ser prevenida y no puede ser corregida, enderezada, borrada, más que por la catástrofe (Castoriadis 2006, p. 339).

\section{Conclusión: La stásis trágica}

Dada la centralidad de la categoría de stásis para la articulación entre tragedia y democracia, delimitamos conceptualmente la stásis trágica como aquella que ha sido presentada en la literatura trágica de Esquilo, Sófocles y Eurípides. Examinar genealógicamente la stásis trágica implica, por un lado, atender aquella imbricación insoluble entre el régimen de lenguaje y discursos políticos en conflicto-erística-, y, por otro, el régimen de las prácticas y acciones-ergein-, en disputa que recaen sobre el cuerpo político de la pólis. Brevemente, destacamos ahora solo cinco dimensiones fundamentales de la stásis trágica.

Primero, en el orden de la erística del lenguaje, la stásis comporta ciertos regímenes discursivos adversativos que comunican tragedia y democracia, en su proceso histórico de emergencia y constitución. Estos regímenes que les ponen en común son isegoría, isonomía y parrhesía (Foucault 2009, pp. 161-181), y ellos configuran unas prácticas discursivas polémicas y agonísticas, una "toma de palabra" de tres tipos: de carácter público-político deliberativos (simbuléuticos); político-judiciales (demósioi); o de litigios privados (idiotikoi) (Demóstenes 2008, p. 15), todos ellos inscriptos y constituyentes de lo que hemos denominado una parrhesía trágico-política" (Arancibia 2016, pp. 283-303).

La stásis define un régimen discursivo íntimamente remitido a la discordia, al pólemos, a la "guerra con palabras" - a la "guerra del discurso"-, constituyendo una erística (Foucault 2009, p. 73). La stásis concierne al lenguaje y al cuerpo, al orden del discurso y a las prácticas, a la asamblea y a la guerra. Así se entiende que, tanto en la tragedia como en la democracia, la guerra la desatan las palabras. Considérese el discurso del Lacedemonio Brasidas contra Atenas: " $Y$ entonces devastaré vuestra tierra, os impondré a la fuerza mi alianza" (Tucídides, IV 86,1). Tucídides explica que 
desatada la stásis, la paz y el entendimiento se retiran hasta de las palabras: "Cambiaron incluso el significado normal de las palabras en relación a los hechos, para adecuarlas a su interpretación de los mismos" (Tucídides 2000, III, 82,3).

Tal como hizo notar Gernet, por ejemplo, Clitemnestra hace gala de su astuta manipulación del lenguaje, pues accede al trono de Argos mediante una treta; tiende una emboscada mediante el lenguaje y así acomete un ataque contra la prerrogativa del poder de Agamenón (Gernet 2002, 137). En la escena de los tapices, la conversación entre la reina y el rey está llena de términos bélicos: maches (batalla o combate, 940); to nikasthai (vencedor o conquistador, 941); deerios (lucha, batalla o competencia, 942); katestrammai (ser sometido, compelido o dominado por otro, 955). "Clitemnestra primero escoge batallar con palabras astutas, no con filosas espadas. Derrota a Agamenón en una competencia verbal para asegurar luego su derrota fisica" (Rocco 1996, p. 198).

Así, la ciudad dividida por la stásis se manifiesta en el lenguaje. En Orestes de Esquilo (884-945) a través de la multiplicidad de voces enteramente contradictorias, irreconciliables, que disputan en la asamblea y que terminan dando como resultado una decisión en extremo escindida y surcada por la amenaza de la lucha sediciosa (Gallego 2014). El lenguaje trágico acoplado a la fuerza pronuncia un discurso polémico, como si fuera un torneo oratorio, una batalla con palabras, palabras anudadas a la fuerza, como si el diálogo se entablara negándose a sí mismo.

Así, la erística trágica implica el exceso de palabra y de fuerza por ambas partes en conflicto; pues, "si estas partes hablan es porque pueden defenderse y porque el espacio de palabra subsiste" (Bollack 2004, p. 7). En ese sentido, la stásis implica un régimen discursivo, parrhesiástico, esencial y constitutivo tanto de la tragedia como de la democracia. De modo que la democracia se encontraría siempre aledaña y expuesta a la tragedia, en cuanto ella pulsa por la homonoia-el acuerdo de las ideas-y la homologia -el acuerdo en las palabras-, pero no puede más que practicarse como diferendo y litigio, como la disputa por alcanzar el consenso tenso y vibratorio propio de la política (Cassin 2008, pp. 157-160).

Segundo, la stásis implica una relación constitutiva del conflicto y lo político (neikos, agón), y este carácter estrictamente agonístico de lo político se expresa, de modo distintivo y palmario, en la tragedia y en la democracia (Vernant; Vidal-Naquet 2008, pp. 23-35). Allí, los agentes disputan por un derecho y una ley (nomos) que postula una justicia (dike), que litiga entre lo conveniente (sympheron) y lo perjudicial (blaberon) (Rancière 1996, pp. 15-25).

La ligazón política entre tragedia y democracia tangencia un agonismo trágico que remite a un nomos en disputa, entre lo dañoso y desgraciado, de lo que es bueno y venturoso para la ciudad (Reinhardt 2010, pp. 85-98). Yace ahí el carácter trágico de la democracia, pues, su agonismo no puede prevenir ni evitar absolutamente el desastre, y en ocasiones no hace más que precipitarlo. Constituida desde el conflicto, tanto la tragedia como la democracia quedan expuestas a fuerzas cuya inclemencia tiene efectos calamitosos sobre la comunidad. Así, el conflicto es lo irrepresentable de lo político, lo incontenible, y de cierto modo, lo ingobernable (Esposito 1996, pp. 19-37). 
Tercero, la stásis comporta una acción política (ergon), que concierne a la práctica y contienda público-política que involucra y compromete el destino político de la comunidad (Platón 2002, VII, 324a, 329c). Tanto la tragedia como la democracia suponen el emprendimiento de acciones, cuya materialidad y concreción afectan directa y decisivamente al "cuerpo político", tanto en su dimensión jurídico-institucional, como en la experiencia vital de la ciudad (Foucault 2009, pp. 230-252). Tal como expone Platón en la Carta VII, el logos filosófico exige la verificación del “ergon", pues aquella ligadura performativa del lenguaje rezuma la verdad de una filosofía, pues si el discurso no se transforma en acción, y si la acción niega el discurso, esta filosofía se muestra "cobarde o embustera" (2002, VII, 329b).

Cuarto, la stásis trágica contiene una dimensión ético-política que abraza tanto a la tragedia como a la democracia. Aquella condición ética a la que Lacan denomina "el brillo de Antígona" (1986: 285), estaría presente en ambas modulaciones, pues tanto la tragedia como la democracia implican la afirmación de una fuerza, una voluntad y decisión, cuya "sustancia ética" resulta constitutiva e irrenunciable para cada agente en conflicto. Su conspicua silueta sería el héroe trágico (Hegel 2006, pp. 527-539).

Esta intensidad ética se evidencia en el agón trágico entre una racionalidad autónoma y una racionalidad heterónoma: expresado paradigmáticamente entre Creonte y Antígona (Reinhardt 2010, pp. 79-108). Asimismo, establece una delicada nervadura histórica entre el héroe trágico y la emergencia del ciudadano democrático. Zizek advierte que el problema en "Antígona" no es su pulsión de muerte, sino que la monstruosidad de su acto queda oculta por la belleza estética del personaje, en cuanto queda excluida de la comunidad, al tiempo que se configura en el símbolo de los que bregan y disputan por la voz, la palabra, el derecho, la ciudadanía (Zizek 2017, pp. 16-33). Hölderlin lo expresa con particular elocuencia:

Seguramente el rasgo supremo de Antígona. La sublime burla, hasta donde la sagrada locura es la más alta manifestación humana, y aquí más alma que lenguaje, supera a todo el resto de sus intervenciones habladas; y es que además, también es necesario hablar así de la belleza, en superlativo, porque la dignidad en la actitud, entre otras cosas, también reside en lo superlativo del espíritu humano y de la virtuosidad heroica (Hölderlin 2014, p. 165).

Así, el héroe trágico oficia una doble figura, paradojalmente, tanto de metáfora como antítesis de la situación del ciudadano democrático. "Es metáfora de lo que en el ciudadano ateniense del siglo V se esboza como voluntad del agente; pues en la configuración del héroe trágico hay una analogía con el ciudadano democrático como agente constituido en torno al problema de la decisión" (Gallego 2012, pp. 73-74). Se podría afirmar que en esta conjunción entre tragedia y democracia se generan y diseminan condiciones para la emergencia de una nueva figura del agente, una emergente "subjetividad política" capaz de la decisión y de la acción, una voluntad ética y política que anuncia la imbricación entre el héroe trágico y el ciudadano democrático (Gallego 2018, p. 220).

Quinto, la stásis trágica remite a la experiencia de un desborde, una desmesura, un desenfreno que conduce al colapso de unas formas y principios reguladores. Allí, la 
stásis se imbrica con un cierto pathos, una hybris que, procurando una dike, no hace más que negarla y postergarla (Vernant 2007, pp. 51-88). La stásis desencadena la hybris y con ella la inclemencia y ferocidad devastadora que condena a la comunidad a la kathastrophé, al sufrimiento até y al dolor ponos (Loraux 2003, pp. 55-57).

Trátase de una condición daimónica, una locura (mainestai) que asiste y se apodera del mundo de los hombres, arrestándoles en la embriaguez de una fuerza y ferocidad ingobernable (Weil 2005, pp. 15-45). “Así, pues, en Corcira se dieron por primera vez la mayor parte de estas barbaridades, con todos los crímenes que hombres gobernados con insolencia más que con moderación por dirigentes que les habian mostrado el camino de la venganza" (Tucídides 2000, III, 84,1).

En esta Hybris de la stásis se produce el desgarramiento (sphagé) de los cuerpos y del cuerpo político de la ciudad como aquella muerte sediciosa desatada por la guerra civil (Loraux 2005, pp. 62-68). La figura emblemática de aquello sería la sphagé de Penteo, pues, a lo largo de "Las Bacantes" es la guerra lo que Dioniso, el mensajero, Penteo y el coro anuncian sin descanso."Se advierte aqui un pensamiento de la stásis que atraviesa la Atenas democrática. La guerra civil recurrente y el uso sistemático de la violencia tornaron ineficaces los dispositivos políticos asamblearios para zanjar las disputas" (Gallego 2014).

Precisamente pensando la condición política de la tragedia, Critchley parafrasea a Carson en su traducción de Eurípides diciendo:

¿por qué existe la tragedia? Porque estás lleno de cólera. ¿Y por qué estás lleno de cólera? Porque estás lleno de dolor. ¿Por qué estás lleno de dolor y de pena? Porque hay guerras por doquier y la gente está muriendo. La tragedia podría definirse como la cólera que mana del dolor provocado por la guerra (Critchley 2014, p. 40).

Estas cinco dimensiones contenidas en la noción de stásis, nos permiten avanzar a evidenciar la comisura categorial entre tragedia y democracia. Si la stásis remite a la inclemencia desoladora de la guerra interna de la ciudad contra sí misma - la comunidad contra la comunidad-, ella define y comporta el agonismo trágico de la política (Tucídides 2000, III, 69, 116).

El concepto de stásis designa el carácter “trágico", en tanto categoría histórica y filosófica que sintetiza el régimen de discurso y de acción política agonal, constitutivo del carácter trágico y litigioso de lo político (Dubos 2010, pp. 3-15). La categoría de stásis permitiría elucidar la contigüidad histórica entre tragedia y democracia, al tiempo que permitiría comprender el riesgo constitutivo sobre el cual se construye histórica y filosóficamente la idea de democracia (Agamben, 2015, pp. 9-31).

\section{Referencias bibliográficas}

Adrados, Francisco (1972), Fiesta, Comedia y Tragedia. Sobre los orígenes griegos del teatro. Barcelona: Editorial Planeta. 
Agamben, Giorgio, et al. (2010), Democracia, ¿en qué estado? Buenos Aires: Ed. Prometeo.

(2014), ¿Qué es un dispositivo? Buenos Aires: Adriana Hidalgo Editora. (2015), La Guerre Civile. Paris: Éditions Points.

Andrade, Nora (2003), Discurso y Poder en la Tragedia y la Historiografía griega. Buenos Aires: Ediciones Eudeba.

Arancibia, Juan Pablo. (2016), Tragedia y Melancolía: Idea de lo trágico en la filosofia política contemporánea. Buenos Aires: Ediciones La Cebra.

Aristóteles (1999a), Poética. Editorial. Madrid: Gredos.

(1999b), Política. Madrid: Editorial Gredos.

(2000), Ética Nicomáquea. Madrid: Editorial Gredos.

(2016), La Constitución de Atenas. Madrid: Editorial Akal.

Benveniste, Émile (1983), Vocabulario de las Instituciones Indoeuropeas. Madrid: Taurus Ediciones.

Boccon-Gibod, Thomas (2008), "La tragédie, entre art et politique. Schmitt, Benjamin, Foucault". Presses de Sciences Po: Raisons politiques 2008/03, n³1, pp. 135149.

Bollack, Jean (2004), La muerte de Antígona. La tragedia de Creonte. Madrid: Arena Libros.

Bowra, C. M. (1969), La aventura griega. Madrid: Ediciones Guadarrama. (1948). Historia de la Literatura Griega. México: F.C.E. Ediciones.

Burckhardt, Jacob (1965), Historia de la Cultura Griega. Barcelona: Editorial Iberia.

Burkert, Walter (2011), El origen salvaje. Rito de sacrificio y mito entre los griegos. Barcelona: Ed. Acantilado.

Butler, Judith (2001), El Grito de Antígona. Barcelona: El Roure Editorial.

Canfora, Luciano (2014), El Mundo de Atenas. Barcelona: Editorial Anagrama.

Cassin, Bárbara (2010), Vocabulaire Européen des Philosophies. Dictionnaire des intradusibles. Paris: Ed. Seuil.

(2008), El Efecto Sofístico. Buenos Aires: Ediciones Fondo de Cultura Económica.

Castoriadis, Cornelius (2006), Lo que hace a Grecia. I. De Homero a Heráclito. Buenos Aires: Fondo de Cultura Económica.

Cataudella, Quintino (1967), Historia de la Literatura Griega. Barcelona: Editorial Iberia.

Chantraine, Pierre (1968), Dictionaire Étymologique de la Langue Grecque. Histoire des mots. Paris: Éditions Klincksieck.

Cohen, Robert (1961), Atenas, una democracia. Desde su nacimiento a su muerte. Barcelona: Aymá Editora.

Cornford, F. M. (1987), Principium Sapientiae. Madrid: Ediciones Visor.

Critchley, Simon (2014), Tragedia y Modernidad. Madrid: Editorial Trotta. 
De Unamuno, Miguel (1984), Del Sentimiento Trágico de la Vida. Madrid: Ed. Orbis. Deleuze, Gilles (1998), Nietzsche y la Filosofía. Barcelona: Editorial Anagrama. (1987), Foucault. Barcelona: Ediciones Paidós. (1999), “Qué es un dispositivo?”. Michel Foucault, filósofo. Balibar, E. Deleuze, G. et al. Barcelona: Gedisa Editorial.

Demóstenes (2008), Discursos ante la Asamblea. Madrid: Ediciones Akal.

Dubos, Nicolas (2010), Le Mal Extrême. La guerre civile vue par les philosophes. Paris: CNRS Éditions.

Eagleton, Terry (2011), Dulce Violencia. La Idea de lo Trágico. Madrid: Editorial Trotta.

Esposito, Roberto (1996), Confines de lo político. Madrid: Editorial Trotta.

Esquilo (2000), Tragedias. Madrid: Editorial Gredos.

Eurípides (2000), Tragedias. Las Bacantes. Madrid: Editorial Gredos.

Farrington, Benjamin (1947), Ciencia Griega. Buenos Aires: Editorial Lautaro.

Festugière, A. J. (1986), La Esencia de la Tragedia Griega. Barcelona: Editorial Ariel. Forrest, W. G. (1966), La Democracia Griega. Madrid: Ediciones Guadarrama.

Foucault, Michel (2009), El Gobierno de sí y de los otros. México: F.C.E. Editores. (2010), El Coraje de la Verdad. México: F.C.E. Editores.

(2012), El saber de Edipo. México: F.C.E. Editores. (2002), El orden del discurso. Barcelona: Ed. TusQuets.

(1997), Nietzsche, la genealogía, la historia. Valencia: Ed. Pre-Textos. (2003), La verdad y las formas jurídicas. Barcelona: Gedisa Editorial.

Gallego, Julián (2003), La democracia en tiempos de tragedia. Madrid: Ed. Miño y Dávila.

(2012), "La democracia ateniense en el desierto de Lemnos. El Filoctetes de Sófocles y la política del dêmos", en L. Sancho; A. Iriarte; J. Gallego (comps.). Lógos y Arkhé. Discurso político y autoridad en la Grecia Antigua. Buenos Aires: Miño y Dávila Editores.

(2011), "El mito de Orestes y el devenir dramático de la democracia. Política y tragedia en la Atenas de fines del siglo V a.C”. Estudios Interdisciplinarios de Historia Antigua III. Argentina: Editorial Brujas.

(2014), "La crisis de la democracia ateniense a través del teatro trágico". Argos, versión on-line ISSN 1853-6379. Argos vol. 37. N1 Ciudad Autónoma de Buenos Aires. Julio 2014. s/n

(2016), "Edipo en Colono y la guerra civil en Atenas". Mètis. Anthropologie des mondes grecs anciens. N.S. 14 2016. pp. 159-183.

(2018), "De la volonté tragique à láction politique: la decisión subjective dans la démocratie athénienne", en S. Georgoudi; et F. De Polignac; Vernant Relire. Paris: Les Belles Lettres. 
García Álvarez, César (2006), La Literatura Clásica Griega. Santiago: Editorial Universitaria.

(2016), "Tragedia, filosofía y política en Esquilo". Byzantion nea hellás. Versión on-line ISSN 0718-8471. Byzantion nea hellás $\mathrm{N}^{\circ} 35$. Santiago noviembre 2016, s/n.

García Gual, Carlos (2018), Los siete sabios. Madrid: Alianza Editorial.

García Velázquez, Antonia (2000), Himnos Homéricos. Batracomiomaquia. Madrid: Akal Ediciones.

Gentili, Carlo y Gianluca Garelli (2015), Lo Trágico. Madrid: Ed. Machado Libros. Gernet, Louis (2002), Anthropologie de la Grèce antique. Paris: Ed. Flammarion (1982), Droit et institutions en Grèce antique. Paris: Ed. Flammarion.

Gil F., Luis (2009), Sobre la democracia ateniense. Madrid: Clásicos Dykinson Editores.

Grüner, Eduardo (2007), "El estado: pasión de multitudes. Spinoza versus Hobbes, entre Hamlet y Edipo".

Hegel, G. W. F. (2006), Filosofía del Arte o Estética. Madrid: Abada Editores.

Heródoto (2000), Historia. Madrid: Editorial Gredos.

Herreras, Enrique (2010), La Tragedia y los mitos democráticos. Madrid: Ed. Biblioteca Nueva.

Hölderlin, Friedrich (2014), “Anotaciones sobre Antígona”. Antígona. Madrid: Ediciones La Oficina.

Homero (2012), Ilíada. Madrid: Abada Editores.

Iriarte, Ana (1996), Democracia y tragedia. La era de Pericles. Madrid: Ed. Akal. Jaeger, Werner (2001), Paideia. México: Fondo de Cultura Económica Ediciones. Jaspers, Karl (1960), Esencia y forma de lo trágico. Buenos Aires: Ediciones Sur. Lacan, Jacques (1986), Le Seminaire. Livre VII. Paris: Éditions du Seuil.

Lasso de la Vega, José (1974), De Sófocles a Brecht. Barcelona: Editorial Planeta. Lesky, Albin (2001), La Tragedia Griega. Barcelona: Acantilado Ediciones. (2009), Historia de la Literatura Griega I-II. Madrid: Editorial Gredos.

Liddell, H. G. \& R. Scott (1958), Greek English Lexicon. Oxford: Oxford University Press.

Loraux, Nicole (2005), La Guerra Civil en Atenas. Madrid: Ediciones Akal. (2007), Mito y Política en Atenas. Buenos Aires: El Cuenco de Plata Ed. (2008), La Ciudad Dividida. Buenos Aires: Editorial Katz. (2003), Las Experiencias de Tiresias. Buenos Aires: Editorial Biblos.

Mas, Salvador (2003), Ethos y Pólis. Una historia de la filosofía práctica en la Grecia Clásica. Madrid: Ediciones Istmo.

Mossé, Claude (2016), Historia de una democracia: Atenas. Madrid: Ediciones Akal. Murray, Gilbert (1947), Historia de la Literatura Clásica Griega. Buenos Aires: Ed. Albatros. 
Nancy, Jean-Luc (2009), La verdad de la democracia. Buenos Aires: Edición Amorrortu.

Nestle, Wilhem (1987), Historia del Espíritu Griego. Barcelona: Editorial Ariel.

Oyarzún, Pablo (2000), "Lo trágico, de Hölderlin a Nietzsche", Revista de Filosofía, Vol. LV-LVI. Santiago: Universidad de Chile.

Persson, Martin (1956), Historia de la religión griega. Buenos Aires: Editorial Universitaria.

Piarists (1943), Diccionario Manual Griego Latino Español de los Padres Escolapios. Buenos Aires: Editorial Albatros.

Platón (1997a), Fedro. Madrid: Editorial Gredos.

(1998), República. Madrid: Editorial Gredos.

(1997b), República. Edición en griego. Madrid: Editorial Centro de Estudios Políticos y Constitucionales.

(2002), Cartas. Madrid: Editorial Gredos.

Plutarco (2000), La Atenas del siglo V. Vidas de Temístocles, Pericles, Nicias y Alcibiades. Madrid: Akal Ediciones.

Rancière, Jacques (1994), En los bordes de lo político. Santiago de Chile: Editorial Universitaria.

Rebok, María Gabriela (2012), La Actualidad de la Experiencia de lo Trágico y el Paradigma de Antígona. Buenos Aires: Ed. Biblos.

Reinhardt, Karl (2010), Sófocles. Madrid: Editorial Gredos.

Rinesi, Eduardo (2011), Política y Tragedia. Buenos Aires: Ediciones Colihue.

Rocco, Christopher (1996), Tragedia e ilustración. El pensamiento político ateniense y los dilemas de la modernidad. Santiago de Chile: Editorial Andrés Bello.

Rodríguez Adrados, Francisco (2011), Nueva historia de la democracia. De Solón a nuestros días. Barcelona: Ariel Editores.

(1963), Introducción a Homero. Madrid: Ediciones Guadarrama.

(1972), Fiesta, comedia y tragedia. Sobre los orígenes griegos del teatro. Barcelona: Editorial Planeta.

Rohde, Erwin (1948), Psique. La idea de Alma y la Inmortalidad entre los Griegos. México: Ediciones Fondo de Cultura Económica.

Rosset, Clément (2010), La Filosofía Trágica. Buenos Aires: Ed. El Cuenco de Plata. Saint Girons, Baldine (2008), Lo Sublime. Madrid: Ediciones A. Machado Libros.

Samaranch, Francisco (1999), Saber del Deseo. Releer a Aristóteles. Madrid: Ed. Trotta.

Schadewaldt, Wolfgang (1981), La Actualidad de la Antigua Grecia. Barcelona: Ed. Alfa.

Scheler, Max (1996), Acerca del fenómeno de lo trágico. Buenos Aires: Ed. Nova.

Scodel, Ruth (2014), La Tragedia Griega. México: Ed. Fondo de Cultura Económica. Simmel, George (1998), El individuo y la libertad. Barcelona: Editorial Península. 
Sófocles (2000), Tragedias. Antígona. Madrid: Editorial Gredos.

Steiner, George (2001), Heidegger. México: Ed. F. C. Económica.

(2011), La Muerte de la Tragedia. Madrid: Ediciones Siruela. (2013), Antígonas. Barcelona: Ediciones Gedisa.

Todorov, Tzvetan (2017), Los enemigos íntimos de la democracia. Barcelona: Galaxia Gutemberg.

Tucídides (2000), Historia de la Guerra del Peloponeso. Madrid: Editorial Gredos.

Vernant, Jean-Pierre (2004), Los Orígenes del Pensamiento Griego. Ed. Paidós. Buenos Aires.

(2007), Mito y Pensamiento en la Grecia Antigua. Barcelona: Ed. Ariel. (2001), La muerte en los ojos. Figuras del otro en la antigua Grecia. Barcelona: Gedisa Editorial.

(2008), Atravesar fronteras. Entre mito y política II. Buenos Aires: Fondo de Cultura Económica.

Vernant, J-P y P. Vidal-Naquet (2002), Mito y Tragedia en la Grecia Antigua. Barcelona: Ed. Paidós.

Vidal Guzmán, G. (2007), Retratos de la Antigüedad Griega. Santiago: Ed. Universitaria.

Vidal-Naquet, Pierre (2001), El Mundo de Homero. México: Fondo de Cultura Económica.

(2004), El Espejo Roto. Tragedia y Política en Atenas en la Grecia Antigua. Madrid: Abada Editores.

Weil, Simone (2005), La Fuente Griega. Madrid: Editorial Trotta.

Williams, Raymond (2014), Tragedia Moderna. Buenos Aires: Editorial Edhasa.

Wilcken, Ulrich (1959), Historia de Grecia. Madrid: Editorial Pegaso.

Zeitlin, Froma (1978), "The dynamics of misogyny: Myth and mythmaking in the Oresteia", Arethusa II, 1-2.

Zizek, Slavoj (2017), Antígona. Madrid: Akal Ediciones. 